Article

\title{
Optimization of Offshoot Outgrowth in Globe Artichoke Using a Combination of Chemical and Mechanical Treatments
}

\author{
Jouhaina Riahi ${ }^{1}$, Carlo Nicoletto ${ }^{2} * * \mathbb{0}$, Ghaith Bouzaein ${ }^{3}$, Mohamed Haj Ibrahim ${ }^{1}$, \\ Ismail Ghezal $^{3}$, Paolo Sambo ${ }^{2}$ (D) and Karima Kouki Khalfallah ${ }^{1}$ \\ 1 Département de Science de Production Végétale et Biotechnologie végétale, Institut National Agronomique \\ de Tunisie, 43, Avenue Charles Nicolle, 1082 Tunis, Mahrajène, Tunisia; jouhaina_riahi@yahoo.fr (J.R.); \\ mohamed_hajbrahim@yahoo.fr (M.H.I.); karima.koukikhalfallah@gmail.com (K.K.K.) \\ 2 Department of Agriculture, Food, Natural Resources, Animals and Environment, Campus of Agripolis, \\ University of Padova, Viale dell'Università 16, 35020 Legnaro (PD), Italy; paolo.sambo@unipd.it \\ 3 Station d'Appui de Manouba, Groupement Interprofessionnel des Légumes (SAM), Manouba 1120, Tunisia; \\ ghaith_bouzaien@yahoo.fr (G.B.); ghezal.i@hotmail.fr (I.G.) \\ * Correspondence: carlo.nicoletto@unipd.it; Tel.: +39-0498272826
}

Received: 7 January 2019; Accepted: 19 February 2019; Published: 22 February 2019

check for updates

\begin{abstract}
The application of cytokinins is a good tool to promote axillary buds in many species, but plant decapitation or leaf cut-back are also suitable methods. This research aims to establish a strategy for artichoke cutting production using a combination of chemical and mechanical treatments. Two experiments were conducted in Tunisia to investigate the effect of 6-benzylamino purine (BAP) on shoot outgrowth in globe artichoke combined with the leaf cut-back at collar level one week after BAP treatment. The first trial was tested in a spring offshoot nursery and the second one in a field of micro-propagated mother plants grown for two years. Five treatments were tested in both experiments: BAP 0 ppm + no cut-back (T1), BAP 0, 100, 200, and 300 ppm + cut-back (T2, T3, $\mathrm{T} 4$, and $\mathrm{T} 5$ respectively). Regarding growth aspects, the highest number of offshoots was obtained in T4 for both trials with an increase of $49.2 \%$ and $37.8 \%$ compared to T2 nursery and field values, respectively. T4 also showed a faster rhythm of shoot emission and the biggest shoot size compared to the other treatments. Significant interactions between BAP treatments and offshoot size were recorded for morphological and weight parameters. Regarding the offshoot mineral composition, relevant differences were observed among BAP treatments; moreover, the higher BAP concentrations induced a significant decrease of $\mathrm{NaCl}$ plant uptake. Therefore, the combination of BAP $200 \mathrm{ppm}$ and the leaf cut-back could be a potential method to enlarge the cutting production of globe artichoke also reducing some stressful conditions.
\end{abstract}

Keywords: Cynara cardunculus L. var.; scolymus (L.) Benth; 6-benzylamino purine; shoots; cut back; quality; cuttings

\section{Introduction}

In the world, globe artichoke (Cynara cardunculus L. var. scolymus (L.) Benth) cultivation covers around 124,941 ha. Its main production sites are in the Mediterranean countries, and they provide around $76 \%$ of worldwide artichoke production [1].

In Tunisia, globe artichoke ranks as the sixth most important vegetable in terms of area, production, and commercialization in local and international markets, especially for the cultivar Violet d'Hyères. In 2015, the total area of globe artichoke cultivation covered 4,400 ha and produced 24,000 tons [2]. According to the statistics, the export price per ton (2095 dinars per ton $=646$ euros per ton) of artichoke 
heads reached more than $166 \%$ of the production costs (1253 dinars per ton $=386$ euros per ton) $[2,3]$. Despite its important and valuable financial gains, only $12 \%$ from the production were exported in 2015 [4].

Quality, precocity, and yield of this vegetable are mainly affected by the unsatisfactory quality of cuttings. Most Tunisian farmers adopt the traditional vegetative propagation method for globe artichoke, mainly using stalks and ovoli (underground dormant buds). Despite its economic profitability, this method seems to be a big source of disease spread [5-8] due to the absence of phytosanitary and quality control of transplants. The production of vitro plants could be an important solution to decrease the risk of contaminated plants and it could virtually produce an unlimited number of identical plants from one plant [9-11]. However, micropropagation is an expensive technique and it is not developed in Tunisia. As a result, the improvement of the vegetative propagation techniques used in the field seems to be a potential strategy to overcome the problem of cutting quality in Tunisia [8].

According to a previous work, it was demonstrated that ovoli that originate from spring offshoots significantly improve agronomic, marketable, and qualitative traits of production [8]. Research has targeted the enlargement of cutting production using many techniques such as the application of exogenous cytokinine, the decapitation or the removal of epigeal part of the plant, and mychorhizes [12].

In fact, the application of exogenous cytokinins such as kinetin and 6-benzylamino purine (BAP) in many crops increases the ratio of cytokinin to auxin in the plant, disrupting the apical dominance that controls branching patterns and plant form, and promotes offshoot outgrowth [13]. The responses of crops to cytokinine treatments differs from one species to another. For example, in horticulture, BAP increases the amount of branching in many herbaceous plants, and in some cases it increases the number of flowers and spikes, as in Phalaenopsis Blume and Dendrobium Sw. orchids [14,15]. Regarding vegetables, BAP accelerates flowering and shoot development in tomato plants [16] and increases the shoot biomass in green leafy crops such as spinach [17]. Moreover, the use of kinetin was reported by many authors, but mainly in in vitro culture for globe artichoke as an important inducer for bud formation during the proliferation phase [18-22].

On the other hand, the removal of the apex by the epigeal part cut-back causes a breakdown of apical dominance, so it promotes a simultaneous development of several offshoots which may originate "ovoli" in globe artichoke mother plants [12]. The low availability of ovoli, especially in early cultivars such as Violet de Provence and Violet d'Hyères, makes the expansion of this crop limited.

To overcome this problem, a production plan for globe artichoke nursery plantlets was applied by the removal of apex and epigeal parts of field mother plants during active growth. After the plant cut-back, the remaining parts, which were stumps, were removed from field to pots. Within one month, it was possible to collect the emitted offshoots periodically as cuttings for new transplantations [23]. Another mechanical technique-the decapitation-was also tested on artichoke plants. Under aseptic conditions, artichoke seedlings aged six weeks were decapitated for shoot proliferation in vitro and it was an effective technique, generating many offshoots from each decapitated explant [24]. According to other authors, the combination of chemical and mechanical treatments in vivo or in vitro to enhance the multiplication of globe artichoke cuttings seems to be more effective than using each technique separately $[6,25,26]$.

All these methods used to produce globe artichoke cuttings were mainly focused on their impact on quantitative parameters of the produced plants, but not in qualitative ones. In fact, an exogenous application of cytokinine may affect the distribution of minerals in the plant. This can also influence the morphology of the plant by increasing fresh weight and plant height [27] or leaf shape, leaf size, and leaf number in some ornamental species [28]. It can also have an impact on the interaction between sink and source organs: Gao et al [29] showed that the foliar spray of BAP increases maize yield by enhancing source and sink capacity. On the other hand, mineral uptake and biomass accumulation can give information about the quality of cuttings, since many macronutrients such as phosphorus and sulfate are involved in molecular and physiological processes linked to root [30] and shoot 
development. Moreover, cytokinins are involved in the cell division process [31], photosynthesis [32], and nutrient uptake [33] in plants so it may influence the chemical aspects of cuttings.

In view of this, the objective of this study was the evaluation of the foliar spray of 6-benzylamino purine effects with different concentrations combined with the leaf cut-back at the collar level of the plant on offshoot production and their quality in terms of biomass and mineral composition.

\section{Materials and Methods}

\subsection{Experimental Site}

The trials were conducted in the experimental area of the Support Station of Manouba (SAM), which is under the supervision of the Inter-professional Group of Vegetables (GIL). It is situated in the north of Tunisia, more precisely in the region of Manouba $\left(36^{\circ} 48^{\prime} \mathrm{N} ; 10^{\circ} 03^{\prime} \mathrm{E}\right.$, altitude $\left.469 \mathrm{~m}\right)$. The local climate of this area is characterized by an upper semi-arid stage (Technical Center of Potato and Artichoke meteorological station, Manouba, Tunisia). The lowest temperature recorded was around $6{ }^{\circ} \mathrm{C}$ in January and the highest one was in July about $34^{\circ} \mathrm{C}$. The rainfall is irregular with an average of $439 \mathrm{~mm}$ per year (Figure 1).

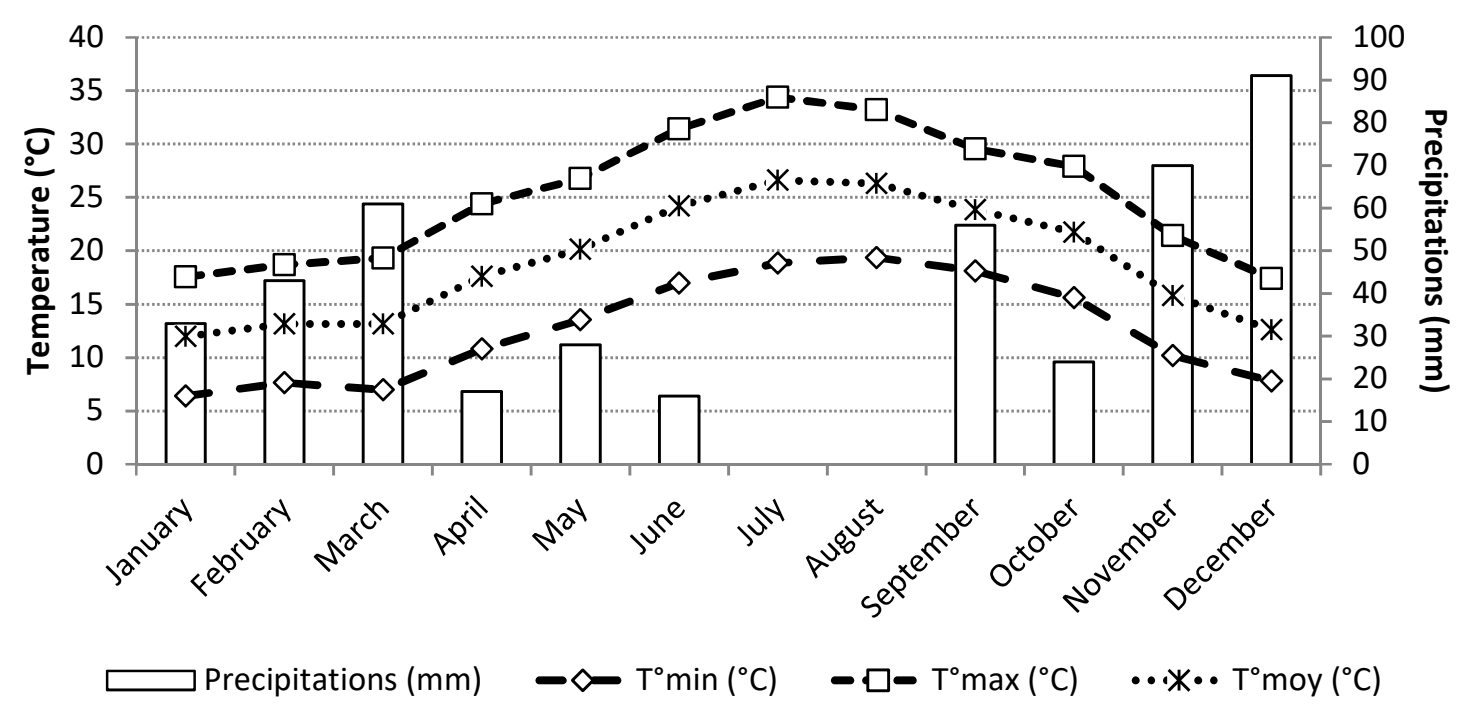

Figure 1. Monthly averages of maximum and minimum air temperatures and cumulative precipitations registered during the year of the essays (Technical Center of Potato and Artichoke meteorological station, Manouba, Tunisia).

\subsection{Plant Material}

To optimize the cutting production for globe artichoke cultivation, two trials were set up in the agronomic experimental station of Manouba using two different vegetative materials from the Violet d'Hyères variety: offshoots and field mother plants.

The nursery of early spring offshoots was established in 4 February 2016. It covered an area of $79 \mathrm{~m}^{2}$ and contained 675 cuttings. At the beginning, offshoots were preselected and removed from controlled and disease-free mother plants located in the SAM globe artichoke field. After that, they were trimmed by $0.15 \mathrm{~m}$ from the base and immersed in a copper hydroxide solution $(50 \%)$ for $2 \mathrm{~min}$ to disinfect them. Then, they were placed on a simple line ridge with a density of 11 plants $\mathrm{m}^{-2}$, respecting gaps of $0.15 \mathrm{~m}$ between the plants and $0.6 \mathrm{~m}$ between ridges.

The field was composed of 2-year-old artichoke mother plants produced from vitro plants by the SAM laboratory. Since its establishment in 2014, the mother plants field was regularly controlled and cleaned of abnormal plants. The plantation density was 6666 plants ha $^{-1}$. Plants were spaced $1 \mathrm{~m}$ apart per row and $1.5 \mathrm{~m}$ between the plantation lines. The trial was realized on a surface of $1057 \mathrm{~m}^{2}$. The soil of the field was a clay type composed of $55 \%$ of clay, $22 \%$ of silt, and $23 \%$ of sand. 
The water used for irrigation was an alkaline drilling water $(\mathrm{pH}=8)$ with $1.2 \mathrm{~g} \mathrm{~L}^{-1}$ of dry residue, electric conductivity $1924 \mu \mathrm{S} \mathrm{cm}{ }^{-1}$, a quite high amount of chlorides $\left(521 \mathrm{mg} \mathrm{L}^{-1}\right)$, and total dissolved salts (TDS) of $966 \mathrm{mg} \mathrm{L}^{-1}$. The crop water consumption was about $740 \mathrm{~mm}$, and its requirements in terms of fertilizers was $316 \mathrm{~kg} \mathrm{ha}^{-1}$ of $\mathrm{N}, 160 \mathrm{~kg} \mathrm{ha}^{-1} \mathrm{P}_{2} \mathrm{O}_{5}$, and $210 \mathrm{~kg} \mathrm{ha}^{-1} \mathrm{~K}_{2} \mathrm{O}$ fractionated depending on crop phases needs.

\subsection{BAP Application}

Different concentrations of exogenous BAP (Sigma Aldrich, Germany) ranging from 0 (T1, T2) to $300 \mathrm{mg} \mathrm{L}^{-1}\left(100,200\right.$, and $\left.300 \mathrm{mg} \mathrm{L}^{-1}\right)$ were sprayed in the same day on the foliage of nursery plants and field mother plants. The powder of BAP was first dissolved in $100 \mathrm{~mL}$ of distilled water containing some drops of $\mathrm{NaOH}$, then fulfilled with pure water until getting the volume of $1 \mathrm{~L}$. Each plant from nursery has received a volume of $10 \mathrm{~mL}$ of BAP solution except those of treatments $\mathrm{T} 1$ and $\mathrm{T} 2$, which were sprayed with the same volume but of distilled water. Field mother plants were treated the same as nursery plants but with a volume of $50 \mathrm{~mL}$ each.

\subsection{Plant Cut-Back}

One week after the application of BAP treatments (3 April 2016), the foliage of plants, except those of T1, were all cut back at the collar level using a sharp saw knife to enhance more outgrowth of offshoots. The treatments were, respectively, T1 (plants sprayed with pure water and not cut back), T2 (plants sprayed with pure water and cut back), T3 (plants sprayed with 100 ppm BAP and cut back), T4 (plants sprayed with 200 ppm BAP and cut back), and T5 (plants sprayed with 300 ppm BAP and cut back).

\subsection{Experimental Design}

For the two trials, the same treatments were applied, and the same experimental design was adopted for the nursery and for the field of artichoke mother plants (Figure 2). The treatments were arranged in a randomized block design with three replications. Each block was constituted by five plots. Each plot was composed of 45 plants for both nursery and field trial irrigated by a drip irrigation system.

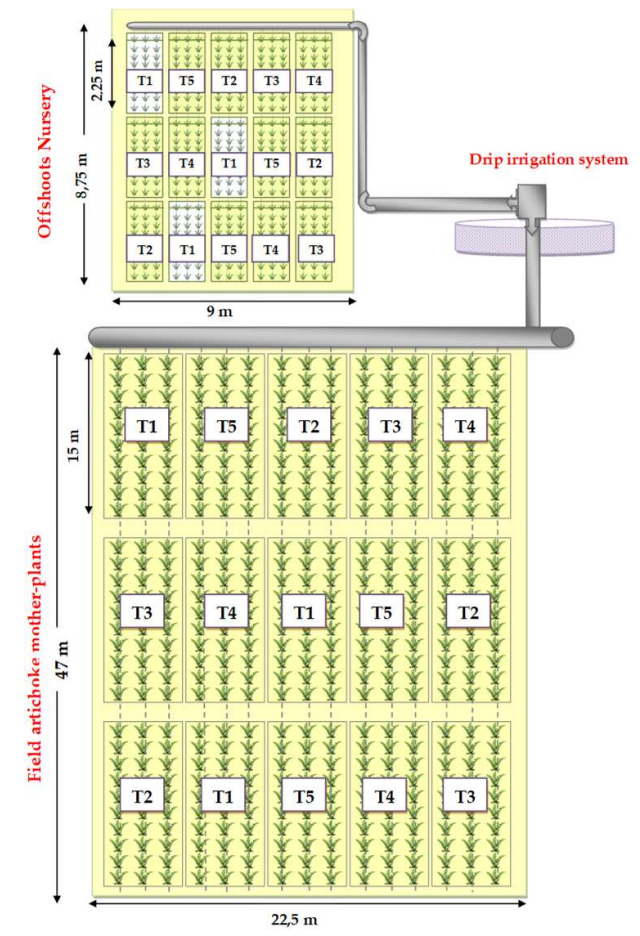

Figure 2. Experimental design for the trials of nursery offshoots and field artichoke mother plants. 


\subsection{Vegetative Growth Parameters for Emitted Offshoots}

Concerning vegetative growth parameters, 15 plants from each plot and each trial were monitored from the 7th day after the cut-back of plants until the 35th day. During this period, the number of emitted offshoots per plant was counted and the offshoot emission rhythm was calculated. On the 36th day after cutting, the emitted offshoots were harvested from the considered plants from each plot. After that, they were weighed and, according their weights, classified into 3 size groups. The adopted offshoot size classification is reported in Table 1.

Table 1. Offshoot classification adopted in the experiment.

\begin{tabular}{lccc}
\hline Name & Description & Weight & Leaf Number \\
\hline NOW1 & & $<30$ & $4-6$ \\
NOW2 & offshoot harvested from nursery plant & $30-60$ & $5-8$ \\
NOW3 & & $>60$ & $6-9$ \\
\hline FOW1 & & $<100$ & $5-6$ \\
FOW2 & offshoot harvested from artichoke field plants & $100-150$ & $6-8$ \\
FOW3 & & $>150$ & $7-9$ \\
\hline
\end{tabular}

After size classification, offshoots were cut into two parts at the collar level to separate the leaves from roots. The number of leaves was counted whereas root length and root diameter was measured for offshoots derived from field plants using a caliper. Therefore, each part from the offshoot was weighed to determine its fresh weight $(\mathrm{g})$, oven-dried $\left(4\right.$ days, $\left.65^{\circ} \mathrm{C}\right)$ and reweighed to determine the dry weight $(\mathrm{g})$ and the dry matter percentage.

\subsection{Determination of Mineral Components of the Harvested Offshoots by Ion Chromatography (IC)}

A total number of 72 offshoots collected from nursery (4 treatments $\times 3$ classes $\times 2$ sampling areas $\times 3$ replications) were used to determine the mineral contents of leaves. For field mother plants, 90 offshoots in total ( 5 treatments $\times 3$ classes $\times 2$ sampling areas $\times 3$ replications) were used for the determination of mineral composition in leaves and in roots. For each analysis, $200 \mathrm{mg}$ of dry matter from each sample were used. Analyses were performed by IC using an ICS-900 Ion Chromatography system (Dionex Corporation, Sunnyvale, CA, USA, which is equipped with a dual piston pump, a model AS-DV auto sampler, an isocratic column at room temperature, a DS5 conductivity detector and an AMMS 300 suppressor $(4 \mathrm{~mm})$ for anions and CMMS 300 suppressor $(4 \mathrm{~mm})$ for cations. Chromeleon 6.5 Chromatography Management Software (ThermoFisher, Sunnyvale, CA, USA) was used for system control and data processing. A Dionex Ion-Pac AS23 analytical column $(4 \mathrm{~mm} \times 250 \mathrm{~mm})$ and a guard column $(4 \mathrm{~mm} \times 50 \mathrm{~mm})$ were used for anion separations, whereas a Dionex IonPac CS12A analytical column $(4 \mathrm{~mm} \times 250 \mathrm{~mm}$ ) (Dionex Corporation, Sunnyvale, CA, USA) and a guard column $(4 \mathrm{~mm} \times 50 \mathrm{~mm})$ (Dionex Corporation, Sunnyvale, CA, USA) were used for cation separations. The eluent consisted of $4.5 \mathrm{mM}$ sodium carbonate and $0.8 \mathrm{mM}$ sodium bicarbonate at a flow rate of

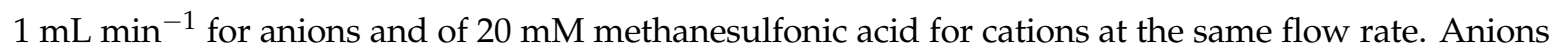
and cations were quantified following a calibration method. Dionex solutions containing seven anions at different concentrations and five cations were taken as standards and the calibration curves were generated with concentrations ranging from $0.4 \mathrm{mg} \mathrm{L}^{-1}$ to $20 \mathrm{mg} \mathrm{L}^{-1}$ and from $0.5 \mathrm{mg} \mathrm{L}^{-1}$ to $50 \mathrm{mg} \mathrm{L}^{-1}$ of standards, respectively.

\subsection{Statistical Analysis}

Data were analyzed by analysis of variance (ANOVA) and treatments were compared with Tukey's Honestly Significant Difference test at the significance level of $p<0.05$. Letters were reported only in the case of significant differences. 


\section{Results and Discussion}

\subsection{Vegetative Parameters for Emitted Offshoots from Nursery Plants}

The monitoring of offshoot formation from nursery plants (Figure 3) revealed significant differences among the applied treatments. T1 nursery plants, which were sprayed with distilled water and without cut-back, were not considered at all because they did not emit offshoots. Seven days after cut-back (DAC), the emission of offshoots started. In fact, the removal of the epigeal part of the plant caused a simultaneous growth of many shoots, which emerged from the soil after 2 or 3 weeks from cut-back [12]. The advanced development of the offshoots was observed especially in nursery T4 plants (treated with 200 ppm of BAP), started by the emission of 2.5 offshoots from the first week after cut-back until almost 7 offshoots at 35 DAC (Figure 4). This period of 35 days was adequate to obtain a satisfactory number of offshoots suitable for direct transplantation or even conservation for a subsequent plantation [23].

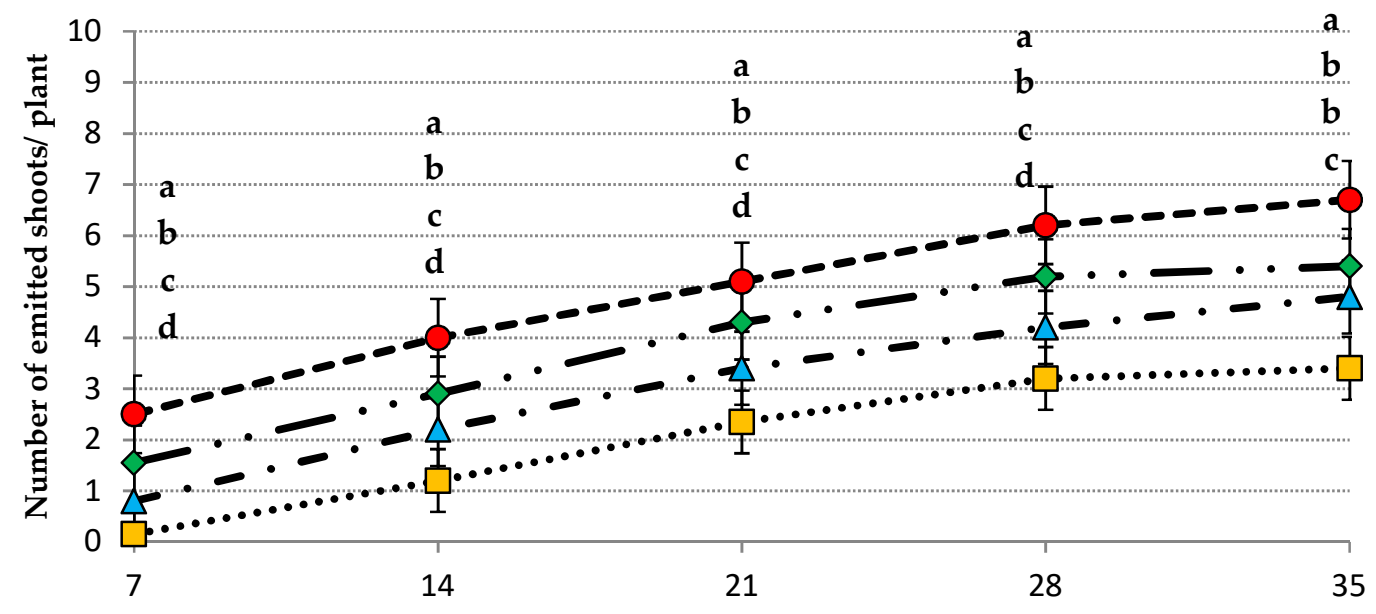

Days after cut back (DAC)

$\cdots \square \cdot \cdot \mathrm{T} 2 \quad-\Delta \cdot \cdot \mathrm{T} 3 \quad-$ ○ T4 $\leadsto \cdot \mathrm{T} 5$

Figure 3. Number of emitted offshoots from nursery plants according to 6-benzylamino purine (BAP) treatments. T2: BAP 0 ppm + cut-back; T3: BAP 100 ppm + cut-back; T4: BAP 200 ppm + cut-back; T5: BAP 300 ppm + cut-back. The central values represent the arithmetic average and the standard deviation is reported by whiskers. Within the same period different letters indicate significant differences according to Tukey's HSD Test at $p<0.05$.

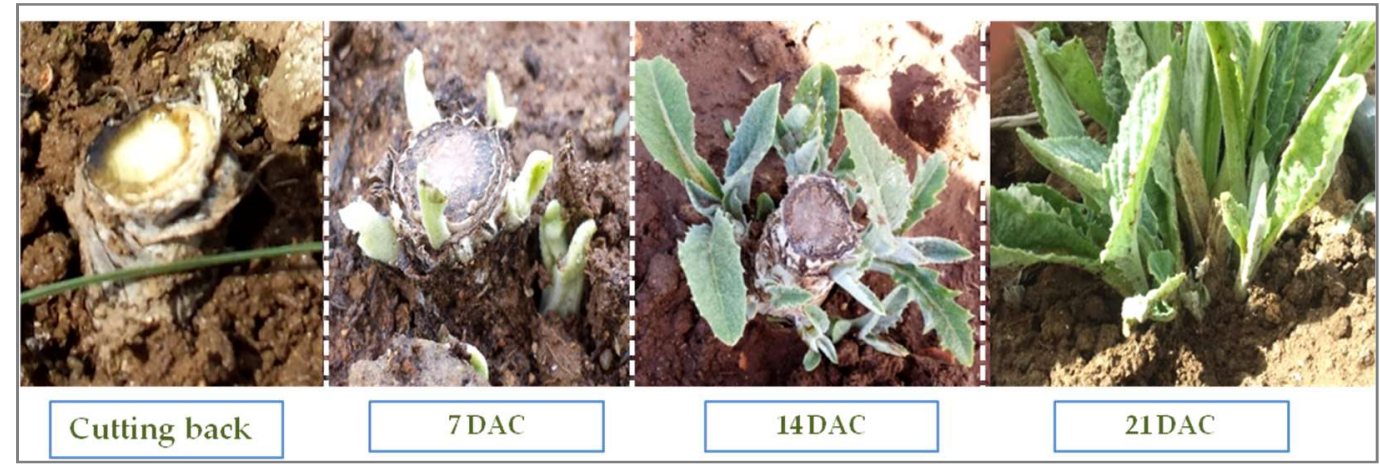

Figure 4. Chronology of offshoot emission from nursery plants of treatment $\mathrm{T} 4$ after cutting back and after $7,14,21$ days after cut-back (DAC).

Besides, previous studies confirmed that the optimal dose of BAP used for the stimulation of the offshoots for globe artichoke was 200 ppm and it increases quadratically the number of emitted 
shoots $[6,25,26]$. Treatments T3 and T5 formed an average of 5 shoots at 35 DAC. T2 treatment displayed the lower formation of offshoots with an average of 3 shoots ( $40 \%$ lower than T3 and T5). The calculation of the emission rate of offshoots for successive periods of 7 days (Supplementary material Table S1) confirmed the superiority of treatment T4 compared to the rest of the treatments from 7 to the 35 DAC except in the second week, followed by treatments T3 and T5. Treatment T2 exhibited the lower emission rhythm over the five weeks.

After the offshoot harvest, three size classes ranging from less than $30 \mathrm{~g}$ to more than $60 \mathrm{~g}$ of fresh weight were chosen. As reported in Table 2, the T2 nursery plants, which received distilled water and were then cut back, produced the highest number of offshoots with a fresh weight lower than $30 \mathrm{~g}$. In fact, offshoots were activated later compared to those sprayed with BAP in the other treatments. For this reason, growers apply exogenous cytokinins to their floriculture and herbaceous crops to activate and to induce the outgrowth of buds and so the branching in plants earlier [34,35]. In fact, adding BAP will disrupt the apical dominance and induce as a result more basal and/or lateral branching and fuller plants [36]. As shown also in Table 2, nursery plants of treatments T4 and T5, treated with the respective doses of $200 \mathrm{ppm}$ and $300 \mathrm{ppm}$ of BAP, produced the weightiest offshoots (around 30\%). This result is connected to the higher number of offshoots that were emitted by T4 and T5 plants 7 DAC. Consequently, they were able to grow more and to develop more biomass. For the nursery offshoot medium weight class (NOW2), nursery plants sprayed with $200 \mathrm{ppm}$ of BAP emitted the highest rate $(60 \%)$ of offshoots with a fresh weight between $30 \mathrm{~g}$ and $60 \mathrm{~g}$ followed by those of treatments $\mathrm{T} 5, \mathrm{~T} 3$, and finally $\mathrm{T} 2$.

Table 2. Percentage distribution of the nursery offshoot weight (NOW) classes according to 6-benzylamino purine (BAP) treatments.

\begin{tabular}{lcccc}
\hline \multicolumn{1}{c}{ BAP Treatments } & T2 & T3 & T4 & T5 \\
\cline { 1 - 5 } Size Class & & & & \\
\hline NOW1 $(\mathrm{fw}<30 \mathrm{~g})$ & $42 \% \mathrm{a}$ & $31 \% \mathrm{~b}$ & $12 \% \mathrm{c}$ & $14 \% \mathrm{c}$ \\
NOW2 $(30 \mathrm{~g} \leq \mathrm{fw} \leq 60 \mathrm{~g})$ & $12 \% \mathrm{c}$ & $22 \% \mathrm{~b}$ & $28 \% \mathrm{a}$ & $30 \% \mathrm{a}$ \\
NOW3 $(\mathrm{fw}>60 \mathrm{~g})$ & & $47 \% \mathrm{c}$ & $60 \% \mathrm{a}$ & $56 \% \mathrm{~b}$ \\
\hline
\end{tabular}

Within the same size class different letters indicate significant differences according to Tukey's HSD Test at $p<0.05$. fw: fresh weight. Standard errors are reported. T2: BAP 0 ppm + cut-back; T3: BAP 100 ppm + cut-back; T4: BAP 200 ppm + cut-back; T5: BAP 300 ppm + cut-back.

According to the results reported in Table 3, the effect of BAP treatments was significant for the aerial part of the collected offshoots and, more precisely, in the number and in the fresh weight of the leaves. The first parameter was significantly higher in T4 and T5, whereas the lower values, below 6 , were found in T2. In addition to a greater number of leaves per plant, their fresh weight was also higher in T4 and T5 with an average leaf unit weight of $7.52 \mathrm{~g}$ and $7.58 \mathrm{~g}$, respectively.

For the underground part of offshoots, the different doses of cytokinins affected the fresh and the dry weight of roots; the higher dose of BAP, the less developed the roots. This result could be in accordance with the findings of Bollmark and Eliasson [37], which demonstrated that an exogenous application of BAP or zeatin inhibits the root formation at a certain dose.

The same effect was also shown in Arabidopsis thaliana (L.) Heynh. by Laplaze et al. [38]. As expected, the different offshoot weight classes significantly influenced the morphological and weight aspects. NOW3 provided the higher number of leaves characterized by greater fresh weight.

Moreover, the average leaf unit weight in NOW3 was $41.6 \%$ higher than that produced by NOW2, demonstrating the greater photosynthetic capacity and the active growth due to the offshoot size. All parameters showed significant interactions among the BAP treatments and the offshoot size (Figure 5).

Fluctuating effects have been found in the leaf dry matter (Figure 5A) in which T2 and T3 expressed high values in NOW3, contrary to that recorded in NOW2, where T4 and T5 showed higher results. Regarding root fresh weight (Figure 5B), the highest values were recorded in T3 for NOW1 
and NOW3, whereas in NOW2, T2 showed the highest weight. Root dry matter (Figure 5C) decreased from $\mathrm{T} 2$ to $\mathrm{T} 5$ for all offshoot size, but in NOW3 T4 values were higher than T3 ones.

Table 3. Characterization of the harvested offshoots from nursery plants according to 6-benzylamino purine (BAP) treatment and to their size classes (NOW).

\begin{tabular}{|c|c|c|c|c|c|c|}
\hline Treatment & $\begin{array}{c}\text { Leaf } \\
\text { Number }\end{array}$ & $\begin{array}{l}\text { Leaf Fresh } \\
\text { Weight (g) }\end{array}$ & $\begin{array}{l}\text { Leaf Average } \\
\text { Weight (g) }\end{array}$ & $\begin{array}{c}\text { Leaf Dry } \\
\text { Matter (\%) }\end{array}$ & $\begin{array}{l}\text { Roots Fresh } \\
\text { Weight (g) }\end{array}$ & $\begin{array}{l}\text { Roots Dry } \\
\text { Matter (\%) }\end{array}$ \\
\hline \multicolumn{7}{|c|}{ BAP Treatments (B) } \\
\hline $\mathrm{T} 2$ & $5.38 \mathrm{c}$ & $37.3 \mathrm{~b}$ & $6.93 \mathrm{~b}$ & 12.7 & $5.72 \mathrm{a}$ & $21.67 \mathrm{a}$ \\
\hline T3 & $6.00 \mathrm{~b}$ & $40.8 \mathrm{~b}$ & $6.80 \mathrm{~b}$ & 12.6 & $5.34 \mathrm{ab}$ & $20.45 \mathrm{~b}$ \\
\hline $\mathrm{T} 4$ & $7.07 \mathrm{a}$ & $53.2 \mathrm{a}$ & $7.52 \mathrm{a}$ & 12.8 & $5.20 \mathrm{~b}$ & $20.20 \mathrm{~b}$ \\
\hline $\mathrm{T} 5$ & $6.62 \mathrm{a}$ & $50.2 \mathrm{a}$ & $7.58 \mathrm{a}$ & 12.7 & $4.66 \mathrm{c}$ & $18.66 \mathrm{c}$ \\
\hline Significances & $* * *$ & $* * *$ & * & $\mathrm{ns}$ & $* * *$ & $* * *$ \\
\hline \multicolumn{7}{|c|}{ NOW Classes (N) } \\
\hline 1 & 4.77 & 15.16 & 3.17 & $13.00 \mathrm{a}$ & $4.30 \mathrm{c}$ & $19.80 \mathrm{~b}$ \\
\hline 2 & 6.50 & 40.6 & 6.24 & $12.2 \mathrm{~b}$ & $5.02 \mathrm{~b}$ & $20.07 \mathrm{~b}$ \\
\hline 3 & 7.53 & 80.4 & 10.67 & $12.9 \mathrm{a}$ & $5.42 \mathrm{a}$ & $20.70 \mathrm{a}$ \\
\hline Significances & & & & $* * *$ & $* * *$ & $* * *$ \\
\hline $\mathrm{B} \times \mathrm{N}$ & & & & $* * *$ & $* * *$ & $* * *$ \\
\hline
\end{tabular}

Within the same trait and for each size class, different letters indicate significant differences according to Tukey's HSD Test at $p<0.05$. T2: BAP 0 ppm + cut-back; T3: BAP 100 ppm + cut-back; T4: BAP 200 ppm + cut-back; T5: BAP 300 ppm + cut-back; NOW1: nursery offshoot fresh weight $\leq 30 \mathrm{~g}$; NOW2: $30 \mathrm{~g}<$ nursery offshoot fresh weight $\leq 60 \mathrm{~g} ;$ NOW3: nursery offshoot fresh weight $>60 \mathrm{~g}$; ns: not significant; ${ }^{*},{ }^{* * *}$ : significant at $p<0.05$ and $p<0.001$ respectively.
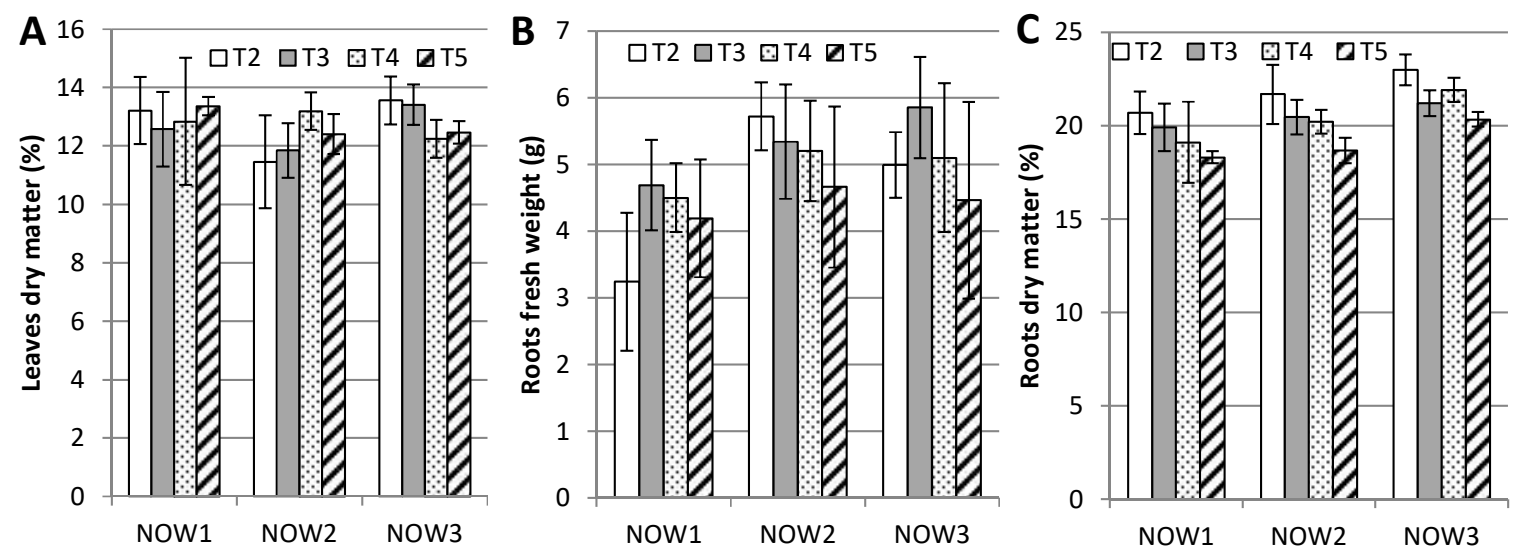

Figure 5. Different effects of 6-benzylamino purine (BAP) treatments on weight traits and dry matter of harvested offshoots from nursery plants according to their size: (A) leaves dry matter, (B) roots fresh weight and $(C)$ roots dry matter. Standard errors are reported. T2: BAP 0 ppm + cut-back; T3: BAP 100 ppm + cut-back; T4: BAP 200 ppm + cut-back; T5: BAP 300 ppm + cut-back; NOW1: nursery offshoot fresh weight $<30 \mathrm{~g}$; NOW2: $30 \mathrm{~g} \leq$ nursery offshoot fresh weight $\leq 60 \mathrm{~g}$; NOW3: nursery offshoot fresh weight $>60 \mathrm{~g}$.

\subsection{Vegetative Growth Parameters for Field Mother Plants}

Following up the offshoot development from artichoke mother plants (cv. Violet d'Hyères) for five weeks after cut-back (Figure 6), significant differences were recorded among the applied treatments. Plants of treatment T4 were the most productive plants in terms of offshoots. In fact, after 7 DAC, T4 plants emitted 15 offshoots each, reaching 21 offshoots after 35 DAC. The lowest number of emitted offshoots was recorded in plants of treatment T1 and it did not exceed 6 offshoots. For treatments T5 and T3, the emission and the development of offshoots were similar (around 16 offshoots). Artichoke 
plants of treatment T2 that were sprayed by distilled water then cut back have emitted about 13 offshoots. For some other varieties reported by Mauromicale et al. [23], the total number of emitted offshoots, after the removal of epigeal part of the plant, was around 21 for clone $9 / 8$ from the Violetto di Sicilia variety and 8.6 for clone ' $\mathrm{C} 3$ ' from the Romanesco variety. Other mechanical techniques were applied on artichoke mother plants in the Brindisino and Violet du Provence varieties. Instead of cutting back the plant, some treatments consisted of the apex removal or in the seasonal harvesting of offshoots from mother plants in autumn and in spring. The periodical picking of offshoots in the two seasons among four years of experiment led to the enhancement of offshoot production with an average of 108,000 offshoots per hectare. It was demonstrated by this trial that globe artichoke mother plant management is a potential strategy to produce high-quality offshoots [39].

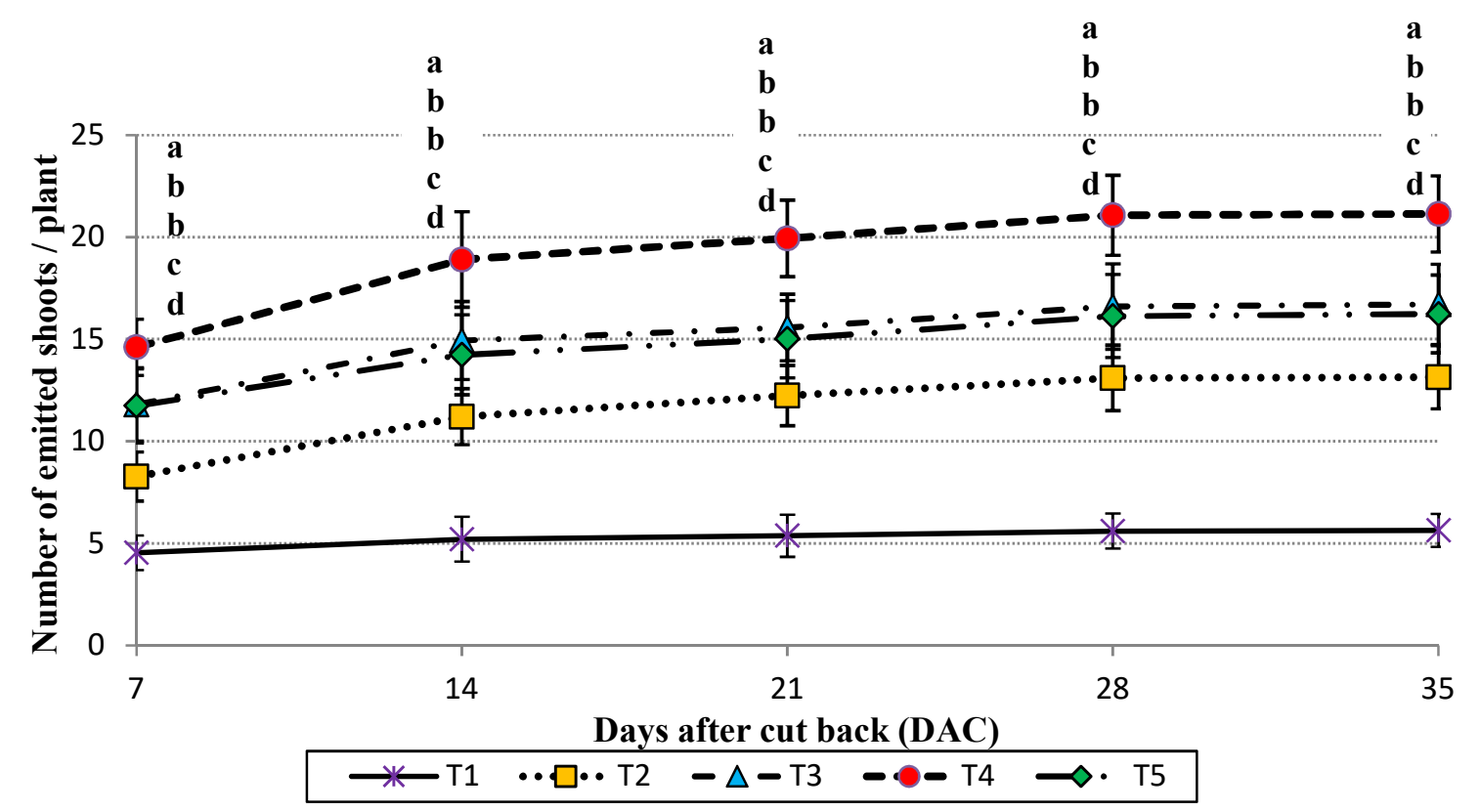

Figure 6. Number of emitted offshoots from field mother plants according to 6-benzylamino purine (BAP) treatments. Within the same period different letters indicate significant differences according to Tukey's HSD Test at $p<0.05$. Standard errors are reported. T1: BAP 0 ppm + no cut-back; T2: BAP 0 ppm + cut-back; T3: BAP 100 ppm + cut-back; T4: BAP 200 ppm + cut-back; T5: BAP 300 ppm + cut-back. The central values represent the arithmetic average and the standard deviation is reported by whiskers.

The calculation of the offshoots emission rate for successive 7 DAC (Supplementary material Table S2) confirmed the superiority of the treatment T4 compared to the rest of treatments except in the last week of observation (from the 28 to 35 DAC) where 55 was the fastest in terms of offshoot emission rate.

According to the measurements of fresh weight of the harvested offshoots from artichoke mother plants, three weight classes were selected as reported in Table 4. Results showed that T1 mother plants produced $34 \%$ of offshoots with the lowest weight class (FOW1). For FOW2, the highest percentage (60\% of the harvested offshoots) was recorded in T2, T4, and T5. For the biggest offshoots that exceed $150 \mathrm{~g}$ of weight, the maximum percentage of distribution reached $40 \%$ in treatments $\mathrm{T} 1$ and $\mathrm{T} 3$.

Considering the offshoot ranking in the third class $(>150 \mathrm{~g}$ ), those of treatment T2 (Table 4) were the highest in terms of leaf number, aerial and underground biomass. According to the results, the formation of the offshoots was not homogenous among treatments for each class. This can be explained by the complexity of the factors that can control the outgrowth of offshoots. In fact, various approaches have been used to analyze the molecular mechanisms of the regulation of the development 
of offshoots. The conventional plant physiological approaches, such as exogenous application of plant hormones, indicate the importance of hormones in regulating offshoot growth [40].

Table 4. Percentage distribution of field offshoot weight (FOW) classes from field mother plants according to 6-benzylamino purine (BAP) treatments.

\begin{tabular}{lccccc}
\hline \multicolumn{1}{c}{ BAP Treatments } & \multirow{2}{*}{ T1 } & T2 & T3 & T4 & T5 \\
Size Class & & & & & \\
\hline FOW1 $(\mathrm{fw} \leq 100 \mathrm{~g})$ & $34 \% \mathrm{a}$ & $13 \% \mathrm{~d}$ & $27 \% \mathrm{~b}$ & $20 \% \mathrm{c}$ & $20 \% \mathrm{c}$ \\
FOW2 $(100 \mathrm{~g}<\mathrm{fw} \leq 150 \mathrm{~g})$ & $27 \% \mathrm{c}$ & $60 \% \mathrm{a}$ & $34 \% \mathrm{~b}$ & $60 \% \mathrm{a}$ & $60 \% \mathrm{a}$ \\
FOW3 (fw $>150 \mathrm{~g})$ & $40 \% \mathrm{a}$ & $27 \% \mathrm{~b}$ & $40 \% \mathrm{a}$ & $20 \% \mathrm{c}$ & $20 \% \mathrm{c}$ \\
\hline
\end{tabular}

Within the same size class different letters indicate significant differences according to Tukey's HSD Test at $p<0.05$. fw: fresh weight, T1: BAP 0 ppm + no cut-back, T2: BAP 0 ppm + cut-back; T3: BAP 100 ppm + cut-back; T4: BAP 200 ppm + cut-back; T5: BAP 300 ppm + cut-back.

The offshoot production from open field mother plants determined significant effects on the plant morphology both in relation to the BAP use and to the offshoot size (FOW) (Table 5). The higher number of leaves was found in the T2 treatment, not sprayed with BAP and characterized by cut-back. This result did not differ from T3 and T5 also characterized by several leaves greater than 7.1; T1, instead, presented the lower values below 7 leaves. The number of leaves clearly influenced the total areal biomass which was higher in T2 (133 g), 18.06\% higher than T1. Also, for this parameter the total fresh weight of the leaves was higher in FOW3, more than $36.8 \%$ and $53.3 \%$ compared to FOW2 and FOW1, respectively. The dry matter percentage did not differ among BAP treatments, with values ranging from $12.0 \%$ to $13.0 \%$. On the other hand, the offshoot size affected the dry matter content and the highest value was found in FOW2 with 13.5\%. With respect to the underground biomass, the roots diameter was conditioned both by the BAP treatments and by the offshoot size. In the first case, T4 and T5 were characterized by a diameter larger than $22 \mathrm{~mm}$, in contrast to the other treatments which settled below $21 \mathrm{~mm}$.

Table 5. Characterization of the harvested offshoots from field mother plants according to 6-benzylamino purine (BAP) treatments and to their size classes.

\begin{tabular}{|c|c|c|c|c|c|c|c|c|}
\hline Treatment & $\begin{array}{c}\text { Leaf } \\
\text { Number }\end{array}$ & $\begin{array}{l}\text { Leaf Fresh } \\
\text { Weight (g) }\end{array}$ & $\begin{array}{c}\text { Leaf Dry } \\
\text { Matter (\%) }\end{array}$ & $\begin{array}{c}\text { Root } \\
\text { Diameter } \\
(\mathrm{mm})\end{array}$ & $\begin{array}{l}\text { Root } \\
\text { Length } \\
(\mathrm{mm})\end{array}$ & $\begin{array}{l}\text { Root Fresh } \\
\text { Weight (g) }\end{array}$ & $\begin{array}{c}\text { Root Dry } \\
\text { Matter (\%) }\end{array}$ & $\begin{array}{c}\text { Shoot/Root } \\
\text { Ratio (fw) }\end{array}$ \\
\hline \multicolumn{9}{|c|}{ BAP Treatments (B) } \\
\hline $\mathrm{T} 1$ & $6.82 \mathrm{c}$ & $109 \mathrm{c}$ & 12.9 & $21.2 \mathrm{~b}$ & $43.5 \mathrm{a}$ & $11.2 \mathrm{ab}$ & $29.6 \mathrm{a}$ & $9.73 b$ \\
\hline $\mathrm{T} 2$ & $7.44 \mathrm{a}$ & $133 \mathrm{a}$ & 12.9 & $21.8 \mathrm{ab}$ & $36.9 \mathrm{~b}$ & $11.7 \mathrm{a}$ & $24.5 \mathrm{bc}$ & $11.3 \mathrm{a}$ \\
\hline T3 & $7.22 \mathrm{ab}$ & $122 \mathrm{~b}$ & 13.0 & $21.7 \mathrm{ab}$ & $35.8 \mathrm{~b}$ & $10.9 \mathrm{abc}$ & $26.4 \mathrm{~b}$ & $11.2 \mathrm{a}$ \\
\hline Significances & $* * *$ & $* * *$ & ns & $* * *$ & $* * *$ & $* * *$ & $* * *$ & $* *$ \\
\hline \multicolumn{9}{|c|}{ FOW Classes (F) } \\
\hline 1 & 5.99 & 81.0 & $12.2 \mathrm{~b}$ & $19.2 \mathrm{c}$ & $36.5 \mathrm{a}$ & $8.96 \mathrm{c}$ & $25.0 \mathrm{~b}$ & $9.41 \mathrm{c}$ \\
\hline 2 & 7.29 & 110 & $13.5 \mathrm{a}$ & $20.7 \mathrm{~b}$ & $39.3 \mathrm{a}$ & $10.6 \mathrm{~b}$ & $27.4 \mathrm{a}$ & $10.4 \mathrm{~b}$ \\
\hline
\end{tabular}

Within the same trait, different letters indicate significant differences according to Tukey's HSD Test at $p<0.05$. Standard errors are reported. T1: 0 ppm + no cut-back; T2: BAP 0 ppm + cut-back; T3: BAP 100 ppm + cut-back; T4: BAP 200 ppm + cut-back; T5: BAP 300 ppm + cut-back; FOW1: field offshoot weight <100 g; FOW2: $100 \mathrm{~g} \leq$ field offshoot weight $\leq 150 \mathrm{~g}$; FOW3: field offshoot weight $>150 \mathrm{~g}$; ns: not significant; ${ }^{* *}{ }^{* * *}$ : significant at $p<0.01$ and $p<0.001$ respectively.

Regarding T1, in addition to presenting roots with the smaller diameter, it was characterized by the greater length of the roots, more than $43 \mathrm{~mm}$. Contrary to the root length that was not affected by the size of the shoot, the root diameter was bigger in FOW3 followed by FOW2 and FOW1. The roots 
morphological descriptors so far reported clearly influenced the roots fresh weight that was higher in T2 and in FOW3.

The roots dry matter percentage was statistically higher in T1 and in FOW2 showing values higher than $29 \%$ and $27 \%$ respectively. Finally, comparing the relationship between the aerial part and the root system fresh weights, the lower values were found in T1 and, obviously, in FOW1; no significant differences were found among the thesis sprayed with BAP. A slight increase in this ratio, although not significant, was observed in T4 and T5. This result agrees with those reported in Figure 6. In fact, T4 and T5 artichoke mother plants emitted the highest number of early offshoots followed by T3, so they had more time for leaf growth and development. Within the evaluated parameters, the effect of BAP treatments was different according to the size of the shoots. Results that are fluctuating and difficult to be interpreted were observed for the roots diameter and their fresh weight (Figure 7A,B).
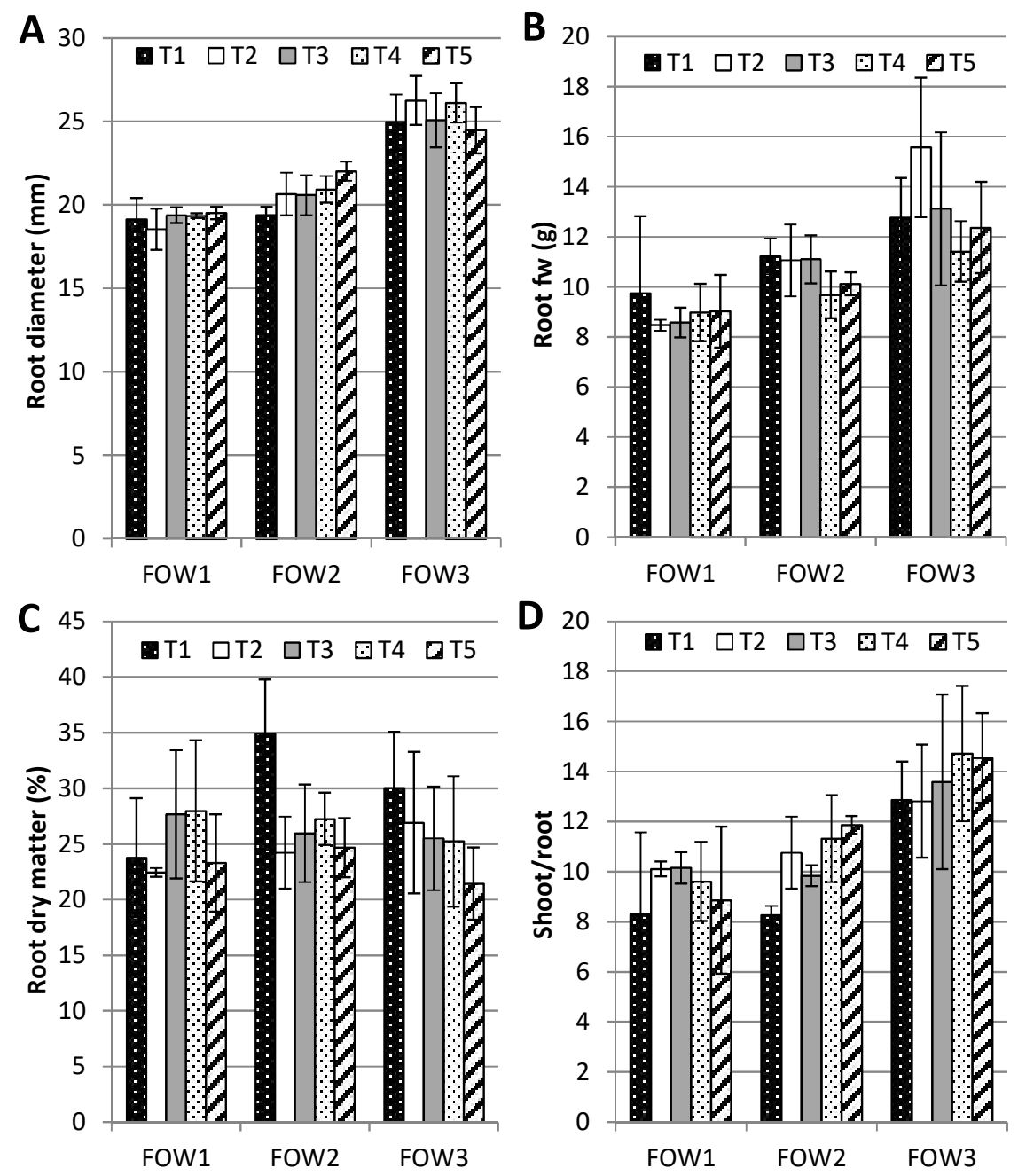

Figure 7. Different effects of 6-benzylamino purine (BAP) treatments on morphological and weight traits of harvested offshoots from field mother plants according to their size: (A) root diameter, (B) root fresh weight, $(\mathbf{C})$ root dry matter, (D) shoot/root ratio. Standard errors are reported. T1: 0 ppm + no cut-back; T2: BAP 0 ppm + cut-back; T3: BAP 100 ppm + cut-back; T4: BAP 200 ppm + cut-back; T5: BAP 300 ppm + cut-back; FOW1: field offshoot weight <100 g; FOW2: $100 \mathrm{~g} \leq$ field offshoot weight $\leq 150 \mathrm{~g}$; FOW3: field offshoot weight $>150 \mathrm{~g}$.

This variation can be attributed to the effect of BAP on nutrient distribution in the plant. Moreover, the largest diameter found in T2 for the offshoots characterized by the greater weight is related to the greater photosynthetic capacity of the leafy apparatus, which allowed storage of more reserve substances. The registered variation of all these biomass parameters in treatments T3, T4, and T5 can 
be attributed to the effect of cytokinins on morphological and physiological aspects of the plant. In fact, cytokinins are involved in the regulation of many important aspects of plant development such as the aerial biomass evolution and root growth [41]. This plant growth regulator (PGR) is part of an intrinsic genetic network controlling organ development and growth and mediates the responses of the plant to variable external factors. These extrinsic factors could be the light for shoots and nutrient availability and water for roots. Indeed, cytokinins have a role in plant responses to biotic and abiotic stress. The combination of these activities contributes to the adjustment of quantitative growth regulation in plants [42]. Still in relation to the root system, the highest dry matter percentage was recorded in T1 at FOW2 and FOW3, whereas in FOW1 the highest values were recorded in T3 and T4.

\subsection{Comparison of Vegetative Parameters between the Harvested Offshoots from Nursery Plants and Those from Field Mother Plants}

Comparing the obtained results between nursery plants and field mother plants in terms of offshoot number and size (Figures 3 and 6) according to treatments, it is obvious that the age of artichoke plants used for vegetative propagation and their development stage influenced directly the mentioned vegetative parameters. In fact, within one week, field mother plants were able to emit 5 to 19 offshoots according to treatments, whereas in nursery plants, the number of emitted offshoots did not exceed 4 . This is a logical and predictable result because artichoke mother plants were planted in the field two years previously so they already developed their above-ground biomass including the formed buds which were three times higher in number than those in nursery plants.

The effect of plant age on the production of offshoots was discussed by Ugur and Eser [43]; they showed that for theSakiz variety, the 3-year-old artichoke mother plants have produced the highest number of offshoots (141.68 offshoots/plant) compared to the ones aged just one year. From another point of view, the emission of offshoots is mainly linked to the root nutrient-stock of plants, which is the nutrition source for offshoot growth and development. There are multiple pathways that control shoot branching in herbaceous plants and it is a kind of spatio-temporal regulation of offshoot outgrowth. Hormones and sugars are among these factors that regulate the outgrowth of offshoots. Sugars are an important source of carbon and energy and they are involved in many physiological processes, just as hormones are in shoot branching. Bud or shoot outgrowth is highly concomitant with starch reserve mobilization in stem tissues especially in perennial plants [44]. In fact, the roots of field mother plants were bigger in size than those of nursery plants, and richer in terms of starch and nutrients. For that reason, the mobilization of the major reserves was destined from the first week after cutting to the outgrowth of numerous offshoots, and then the rhythm was remarkably decreased. The existence of a well-known positive correlation between roots and shoots was connected to a root size increase and an increase in size of tops. Moreover, the root system must be sufficiently widespread to absorb enough water and nutrients for the stem and leaves, which, in turn, must manufacture sufficient food for the maintenance of the root system. In the case of the nursery, plants were forming and developing their root systems to assimilate nutrients and water and to be able to activate progressively the outgrowth of offshoots.

The size of emitted offshoots was directly connected to the emitted number, plant age, morphology, and reserves, but also to the bud position in the plant and its outgrowth timing. In our case, for example, the weight of emitted offshoots in nursery plants was fluctuating under $30 \mathrm{~g}$ (NOW 1) and up to $60 \mathrm{~g}$ (NOW 3) whereas in the field of artichoke mother plants, it was fewer than $100 \mathrm{~g}$ (FOW 1) and more than $150 \mathrm{~g}$ in FOW 3. Rameau et al. [45] indicated that the outgrowth timing of buds depends on the dynamics of hormones, nutrients such as sugars, and possibly light signals perceived by the bud. Those physiological processes are in a relationship with bud position in the plant [46-48], and with other endogenous and external factors.

The common point between the two essays is that the combination of the foliar application of BAP and the cut-back of plants one week later has enhanced the production of offshoots, especially with the dose of 200 ppm of BAP [6,7]. 


\subsection{Mineral Composition of the Harvested Offshoots Collected from Nursery Plants and Field Mother Plants}

According to the analyses of leaf mineral compounds in the emitted shoots of nursery plants (Table 6), significant differences were found among BAP treatments for all the considered elements, whereas NOW classes were not affected by relevant changes. Regarding BAP treatments, the highest concentrations of minerals were generally found in T2 and T3. The only elements that showed higher values in T4 were ammonium, calcium, and nitrates, whereas the content of $\mathrm{PO}_{4}{ }^{3-}$ and $\mathrm{NO}_{3}{ }^{-}$was high in T5. For the latter element, the quantity found in T5 and T4 was $94.1 \%$ higher and 93.3\% higher than T2. This result is mainly linked to the greater exploration capacity of the roots compared to T2 and T3 due to a greater root biomass. It is interesting to note that the concentration of chlorides and sodium was significantly higher in T2 and T3 compared to T4 and T5 and this suggest that these emitted shoots accumulated salts in the leaves. Similar results were also recorded for the offshoots harvested from field mother plants (Table 7).

Table 6. Effect of BAP treatments on mineral contents in leaves of the harvested offshoots from nursery plants.

\begin{tabular}{|c|c|c|c|c|c|c|c|c|c|}
\hline \multirow{3}{*}{ Treatments } & \multicolumn{9}{|c|}{ Mineral Composition } \\
\hline & $\mathrm{Cl}^{-}$ & $\mathrm{PO}_{4}{ }^{3-}$ & $\mathrm{SO}_{4}{ }^{2-}$ & $\mathrm{Na}^{2+}$ & $\mathrm{NH}_{4}{ }^{+}$ & $\mathrm{K}^{+}$ & $\mathrm{Mg}^{2+}$ & $\mathrm{Ca}^{2+}$ & $\mathrm{NO}_{3}{ }^{-}$ \\
\hline & \multicolumn{9}{|c|}{$\left(\mathrm{g} \mathrm{kg}^{-1} \mathrm{dw}\right)$} \\
\hline \multicolumn{10}{|c|}{ BAP Treatments (B) } \\
\hline $\mathrm{T} 2$ & $56.9 \mathrm{a}$ & $5.87 \mathrm{ab}$ & $6.82 \mathrm{a}$ & $11.4 \mathrm{ab}$ & $0.48 \mathrm{~b}$ & $44.0 \mathrm{a}$ & $2.55 \mathrm{ab}$ & $8.78 \mathrm{ab}$ & $0.09 \mathrm{c}$ \\
\hline T3 & $59.3 \mathrm{a}$ & $5.54 \mathrm{ab}$ & $4.65 \mathrm{~b}$ & $13.6 \mathrm{a}$ & $0.55 \mathrm{ab}$ & $39.3 \mathrm{ab}$ & $3.00 \mathrm{a}$ & $9.69 \mathrm{a}$ & $0.44 \mathrm{~b}$ \\
\hline $\mathrm{T} 4$ & $50.6 \mathrm{~b}$ & $4.88 \mathrm{~b}$ & $4.47 \mathrm{~b}$ & $9.03 \mathrm{~b}$ & $0.63 \mathrm{a}$ & $37.7 \mathrm{~b}$ & $2.39 \mathrm{ab}$ & $9.19 \mathrm{a}$ & $1.34 \mathrm{a}$ \\
\hline $\mathrm{T} 5$ & $42.6 \mathrm{c}$ & $7.01 \mathrm{a}$ & $3.58 \mathrm{~b}$ & $9.23 \mathrm{~b}$ & $0.44 \mathrm{~b}$ & $36.8 \mathrm{~b}$ & $2.12 \mathrm{~b}$ & $7.03 \mathrm{~b}$ & $1.52 \mathrm{a}$ \\
\hline Significances & $* * *$ & * & $* * *$ & $* * *$ & $* *$ & * & * & * & $* * *$ \\
\hline \multicolumn{10}{|c|}{ NOW Classes (F) } \\
\hline 1 & 51.0 & 5.58 & 4.92 & 10.3 & 0.50 & 37.9 & 2.23 & 8.47 & 0.75 \\
\hline 2 & 52.1 & 5.94 & 4.67 & 10.9 & 0.52 & 39.8 & 2.52 & 8.59 & 0.83 \\
\hline 3 & 53.9 & 5.95 & 5.06 & 11.2 & 0.56 & 40.6 & 2.79 & 8.94 & 0.97 \\
\hline Significances & ns & ns & ns & ns & ns & ns & ns & ns & ns \\
\hline $\mathrm{B} \times \mathrm{F}$ & ns & ns & ns & ns & ns & $\mathrm{ns}$ & $\mathrm{ns}$ & ns & $\mathrm{ns}$ \\
\hline
\end{tabular}

These results lead us to suggest, as previously mentioned in Table 6, that the offshoots of treatment T2 and T3 accumulated NaCl. In addition, Table 8 also shows that the amounts of chlorides and sodium were higher in the root system of T3 offshoots. Both mineral analyses of offshoots derived from nursery (Table 6) and field (Table 7) showed that the collected offshoots from plants treated with a dose of 100 ppm of BAP and then cut-back to accumulate salt. This accumulation of salts could be a physiological response of the plant to tolerate salinity [49] and the application of BAP could alleviate salt stress [50]. Many researchers have reported the effect of BAP or cytokinine in general on improving the tolerance of several plants [51] to salinity such as tobacco [52] and wheat [53]. Moreover, it was verified that the exogenous application of 6-benzylamino-purine stimulates the plant growth of eggplants, fodder, and sea beets under salt stress [54,55]. Plant responses under stress conditions such as salinity and heat stress depend on the levels of phytohormones and their interactions. Also, crops respond in different ways to PGR according to species, cultivar, growing conditions, the PGR, and the doses used [56]. Indeed, BAP is one of the most well-reported phytohormones that induces various plant responses [57]. In fact, a combination of BAP and gibberellins with a certain dose induce a high shoot growth for tomato under different abiotic stresses [57]; conversely, in barley plants, a supplementary BAP application inhibits the growth during stress conditions without affecting the 
shoot/root ratio [58]. Although there is identification of several cytokinins, their physiological function in each crop is still not completely understood and only a few enzyme activities affecting biosynthesis and metabolism of cytokinins in vivo were identified [59,60]. Consequently, actual research is mainly focused on cytokinin homeostasis and signaling components as a pathway to improve the level of plant tolerance to biotic and abiotic stresses [41].

Table 7. Effect of 6-benzylamino purine (BAP) treatments on mineral contents in leaves of the harvested offshoots from field mother plants.

\begin{tabular}{|c|c|c|c|c|c|c|c|c|c|}
\hline \multirow{3}{*}{ Treatments } & \multicolumn{9}{|c|}{ Mineral Composition of Leaves } \\
\hline & $\mathrm{Cl}^{-}$ & $\mathrm{PO}_{4}{ }^{3-}$ & $\mathrm{SO}_{4}{ }^{2-}$ & $\mathrm{Na}^{2+}$ & $\mathrm{NH}_{4}{ }^{+}$ & $\mathrm{K}^{+}$ & $\mathrm{Mg}^{2+}$ & $\mathrm{Ca}^{2+}$ & $\mathrm{NO}_{3}-$ \\
\hline & \multicolumn{9}{|c|}{$\left(\mathrm{g} \mathrm{kg}^{-1} \mathrm{dw}\right)$} \\
\hline \multicolumn{10}{|c|}{ BAP Treatments (B) } \\
\hline $\mathrm{T} 1$ & $50.6 \mathrm{~cd}$ & $6.62 \mathrm{a}$ & $6.16 \mathrm{a}$ & $14.1 \mathrm{C}$ & 1.12 & $40.8 \mathrm{a}$ & $2.27 \mathrm{~b}$ & 9.25 & $6.65 \mathrm{ab}$ \\
\hline $\mathrm{T} 2$ & $57.8 \mathrm{ab}$ & $6.14 \mathrm{a}$ & $6.63 \mathrm{a}$ & $17.2 \mathrm{ab}$ & 1.20 & $42.9 \mathrm{a}$ & $2.53 \mathrm{ab}$ & 8.73 & $5.66 \mathrm{~b}$ \\
\hline $\mathrm{T} 3$ & $60.1 \mathrm{a}$ & $5.32 \mathrm{ab}$ & $5.00 \mathrm{~b}$ & $19.0 \mathrm{a}$ & 1.27 & $39.7 \mathrm{ab}$ & $3.17 \mathrm{a}$ & 9.75 & $6.08 \mathrm{ab}$ \\
\hline $\mathrm{T} 4$ & $54.3 \mathrm{bc}$ & $4.35 \mathrm{~b}$ & $4.51 \mathrm{~b}$ & $15.4 \mathrm{bc}$ & 1.33 & $37.6 \mathrm{~b}$ & $2.34 \mathrm{~b}$ & 9.08 & $7.14 \mathrm{a}$ \\
\hline $\mathrm{T} 5$ & $47.5 \mathrm{~d}$ & $6.77 \mathrm{a}$ & $4.71 \mathrm{~b}$ & $15.7 \mathrm{bc}$ & 1.13 & $37.6 \mathrm{~b}$ & $2.26 \mathrm{~b}$ & 8.38 & $7.36 \mathrm{a}$ \\
\hline Significances & $* * *$ & $* *$ & $* * *$ & $* * *$ & ns & $*$ & * & ns & * \\
\hline \multicolumn{10}{|c|}{ FOW Classes (F) } \\
\hline 1 & 53.2 & 5.68 & 5.21 & 16.1 & 1.20 & 39.6 & 2.48 & 9.02 & 6.41 \\
\hline 2 & 54.3 & 5.90 & 5.46 & 16.3 & 1.22 & 39.8 & 2.54 & 9.11 & 6.65 \\
\hline 3 & 54.6 & 5.95 & 5.54 & 16.4 & 1.21 & 39.8 & 2.52 & 8.98 & 6.68 \\
\hline Significances & ns & ns & ns & ns & ns & ns & ns & ns & ns \\
\hline $\mathrm{B} \times \mathrm{F}$ & ns & ns & ns & ns & ns & ns & ns & ns & ns \\
\hline
\end{tabular}

Within the same trait, different letters indicate significant differences according to Tukey's HSD Test at $p<0.05$. Dw: dry weight; T1: 0 ppm + no cut-back; T2: BAP 0 ppm + cut-back; T3: BAP 100 ppm + cut-back; T4: BAP 200 ppm + cut-back; T5: BAP 300 ppm + cut-back; FOW1: field offshoot weight < $100 \mathrm{~g}$; FOW2: $100 \mathrm{~g} \leq$ field offshoot weight $\leq 150 \mathrm{~g}$; FOW3: field offshoot weight $>150 \mathrm{~g}$; ns: not significant; ${ }^{*},{ }^{* *},{ }^{* * *}$ : significant at $p<0.05, p<0.01$ and $p<$ 0.001 respectively.

Table 8. Effect of BAP treatments on mineral contents in roots of the harvested offshoots from field mother plants.

\begin{tabular}{|c|c|c|c|c|c|c|c|c|c|}
\hline \multirow{3}{*}{ Treatments } & \multicolumn{9}{|c|}{ Mineral Composition of Root } \\
\hline & $\mathrm{Cl}^{-}$ & $\mathrm{PO}_{4}{ }^{3-}$ & $\mathrm{SO}_{4}^{2-}$ & $\mathrm{Na}^{2+}$ & $\mathrm{NH}_{4}{ }^{+}$ & $\mathbf{K}^{+}$ & $\mathrm{Mg}^{2+}$ & $\mathrm{Ca}^{2+}$ & $\mathrm{NO}_{3}{ }^{-}$ \\
\hline & \multicolumn{9}{|c|}{$\left(\mathrm{g} \mathrm{kg}^{-1} \mathrm{dw}\right)$} \\
\hline \multicolumn{10}{|c|}{ BAP Treatments (B) } \\
\hline $\mathrm{T} 1$ & $3.73 \mathrm{~d}$ & $3.56 \mathrm{a}$ & $0.88 \mathrm{~b}$ & $1.47 \mathrm{~d}$ & $0.18 \mathrm{c}$ & $10.1 \mathrm{c}$ & $1.05 \mathrm{~b}$ & 5.34 & $0.45 c$ \\
\hline $\mathrm{T} 2$ & $9.21 \mathrm{~b}$ & $3.19 \mathrm{ab}$ & $1.08 \mathrm{~b}$ & $4.96 \mathrm{~b}$ & $0.25 \mathrm{~b}$ & $12.7 \mathrm{~b}$ & $1.17 \mathrm{ab}$ & 5.15 & $2.67 \mathrm{~b}$ \\
\hline T3 & $14.3 \mathrm{a}$ & $2.62 \mathrm{~b}$ & $1.53 \mathrm{a}$ & $8.71 \mathrm{a}$ & $0.35 \mathrm{a}$ & $15.2 \mathrm{a}$ & $1.40 \mathrm{a}$ & 5.99 & $4.47 \mathrm{a}$ \\
\hline $\mathrm{T} 4$ & $7.50 \mathrm{c}$ & $3.33 \mathrm{ab}$ & $1.36 \mathrm{a}$ & $2.97 \mathrm{c}$ & $0.23 \mathrm{a}$ & $14.8 \mathrm{a}$ & $1.22 \mathrm{ab}$ & 5.33 & $2.53 \mathrm{~b}$ \\
\hline $\mathrm{T} 5$ & $8.44 \mathrm{bc}$ & $3.04 \mathrm{ab}$ & $1.04 \mathrm{~b}$ & $4.14 \mathrm{bc}$ & $0.29 \mathrm{~b}$ & $12.7 \mathrm{~b}$ & $1.30 \mathrm{ab}$ & 4.95 & $4.02 \mathrm{a}$ \\
\hline Significances & $* * *$ & $*$ & $* * *$ & $* * *$ & $* * *$ & $* * *$ & $*$ & ns & $* * *$ \\
\hline \multicolumn{10}{|c|}{ FOW Classes (F) } \\
\hline 1 & 8.13 & 3.07 & $1.09 \mathrm{~b}$ & 4.23 & $0.23 \mathrm{~b}$ & 12.7 & 1.15 & 5.03 & $2.59 \mathrm{~b}$ \\
\hline 2 & 8.77 & 3.15 & $1.19 \mathrm{ab}$ & 4.45 & $0.26 \mathrm{ab}$ & 13.6 & 1.24 & 5.32 & $2.80 \mathrm{ab}$ \\
\hline 3 & 9.00 & 3.23 & $1.25 \mathrm{a}$ & 4.68 & $0.29 \mathrm{a}$ & 13.4 & 1.29 & 5.71 & $3.09 \mathrm{a}$ \\
\hline Significances & ns & ns & * & ns & * & ns & ns & ns & * \\
\hline $\mathrm{B} \times \mathrm{F}$ & ns & ns & ns & ns & ns & ns & ns & ns & ns \\
\hline
\end{tabular}

Within the same trait, different letters indicate significant differences according to Tukey's HSD Test at $p<0.05$. Dw: dry weight; T1: 0 ppm + no cut-back; T2: BAP 0 ppm + cut-back; T3: BAP 100 ppm + cut-back; T4: BAP 200 ppm + cut-back; T5: BAP 300 ppm + cut-back; FOW1: field offshoot weight <100 g; FOW2: $100 \mathrm{~g} \leq$ field offshoot weight $\leq 150 \mathrm{~g}$; FOW3: field offshoot weight $>150 \mathrm{~g}$; ns: not significant; ${ }^{*}{ }^{* * *}$ : significant at $p<0.05, p<0.01$ and $p<0.001$ respectively. 
With respect to the mineral composition of the root system, results showed that the foliar spray of BAP combined with the cut-back of plant leaf improves the mineral uptake of offshoots from mother plants compared to the control plants (T1). In fact, nutritional control of root development may be mediated by hormone concentration, transport, and/or sensitivity. Indeed, mineral compounds such as nitrate, phosphate, and sulfate can be perceived by cells as signals that can be involved in molecular mechanisms which control cell division and differentiation within roots, and so on, its architecture [30].

It is also interesting to note that potassium is the major element present in the roots of T1, T2, and T3. As previously reported, the high presence of sodium chloride in soil and in irrigation water may have resulted in a significant water stress to the crop. In these conditions, potassium is essential in the maintenance of osmotic potential and water uptake and has a positive impact on stomatal closure, which increases tolerance to water stress [61,62]. Moreover, it is involved in activating a wide range of enzyme systems, which regulate photosynthesis, water use efficiency and movement, nitrogen uptake, and protein building [63,64]. In this regard, Thalooth et al. [65] found that potassium application improves the water content in the broad bean leaves and the plants showed more tolerance to drought stress. Regarding the size of the shoots, no significant changes in the leaf mineral composition were observed, whereas in the root system some significant differences were noticed. The $\mathrm{SO}_{4}{ }^{2-}, \mathrm{NH}_{4}{ }^{+}$and $\mathrm{NO}_{3}{ }^{-}$amount were higher in FOW3 probably due, also in this case, to the higher capability to explore the soil or to better nourishment provided by the mother plant.

\section{Conclusions}

The obtained results from the two experiments show clearly that the combination of BAP treatments and the cut-back of plants one week later enhanced the outgrowth of offshoots by activating the offshoot development. The optimum dose of BAP was $200 \mathrm{ppm}$ to reach the maximum number of offshoots from both nursery plants and field mother plants. The BAP doses affected the offshoot quality in terms of mineral compounds, also highlighting a positive effect on the reduction of stressful conditions at higher concentration. These results lead to the affirmation that the combination of cytokinin treatments and plant cut-back would be a promising technique to enlarge the scale of cutting production. Farmers could produce for their new transplantations a satisfactory number of cuttings using this simple technique in a limited surface. In fact, a nursery of $126 \mathrm{~m}^{2}$, considering a density of offshoot plantation of 11 plants $\mathrm{m}^{-2}$, can theorically produce one hectar of controlled cuttings (8333 ovoli) with low cost and using only $2.6 \mathrm{~g}$ of BAP powder. it is also possible for farmers to use their fields destinated for grubbing as elementary plots with selected plants for cutting production, considering 147 mother plants and $1.5 \mathrm{~g}$ of BAP powder to produce enough ovoli for 1 ha.

Supplementary Materials: The following are available online at http:/ /www.mdpi.com/2073-4395/9/2/104/s1, Table S1: Emission rhythm of offshoots from nursery plants according to 6-benzylamino purine (BAP) treatments; Table S2: Rhythm of offshoot emission per week according to 6-benzylamino purine (BAP) treatments applied on field mother plants.

Author Contributions: J.R., C.N., P.S., K.K.K. and I.G. conceived and designed the experiments; J.R., C.N., M.H.I. and G.B. performed the experiments; J.R. and C.N. analyzed the data; J.R. and C.N. wrote the paper.

Conflicts of Interest: The authors declare no conflict of interest.

\section{Abbreviations}

$\begin{array}{ll}\text { ANOVA } & \text { Analysis of Variance } \\ \text { BAP } & \text { 6-benzylamino purine } \\ \text { NOW } & \text { nursery offshoots weight classes } \\ \text { FOW } & \text { field offshoots weight classes } \\ \text { CTPTA } & \text { Center Technique de Pomme de Terre et d'Artichaut } \\ \text { DAC } & \text { Days after cutting back } \\ \text { DGEDA } & \text { Direction générale des études et de développement agricole } \\ \text { GIL } & \text { Inter-professional Group of Vegetables } \\ \text { IC } & \text { Ion Chromatography }\end{array}$




$\begin{array}{ll}\text { ONAGRI } & \text { Observatoire National de l'agriculture } \\ \text { SAM } & \text { Support Station of Manouba } \\ \text { T1 } & \text { Plants sprayed with pure water and not cut back } \\ \text { T2 } & \text { Plants sprayed with pure water and cut back } \\ \text { T3 } & \text { Plants sprayed with } 100 \text { ppm BAP and cut back } \\ \text { T4 } & \text { Plants sprayed with } 200 \text { ppm BAP and cut back } \\ \text { T5 } & \text { Plants sprayed with } 300 \text { ppm BAP and cut back }\end{array}$

\section{References}

1. FAOSTAT. 2017. Available online: http://www.fao.org/faostat/en/ (accessed on 20 December 2018).

2. CTPTA. Rapport d'activités du Centre Technique de Pomme de Terre et d'Artichaut; Essaida: Manouba, Tunisie, 2016.

3. DGEDA. Rapport d'activité 2015; Direction générale des études et de développement Agricole: Belvèdère, Tunis, 2015.

4. ONAGRI. Rapport Annuel 2015. Observatoire National de l'agriculture. Available online: http:/ / www. onagri.nat.tn/uploads/statistiques/annuaire-stat-2015.pdf (accessed on 20 December 2018).

5. Armengol, J.; Berbegal, M.; Giménez-Jaime, A.; Romero, S.; Beltrán, R.; Vicent, A.; García-Jiménez, J. Incidence of Verticillium wilt of artichoke in eastern Spain and role of inoculum sources on crop infection. Phytoparasitica 2005, 33, 397. [CrossRef]

6. Cardarelli, M.; Rouphael, Y.; Saccardo, F.; Colla, G. An innovative vegetative propagation system for large-scale production of globe artichoke transplants. Part I. Propagation system setup. HortTechnology 2005, 15, 812-816. [CrossRef]

7. Cardarelli, M.; Rouphael, Y.; Saccardo, F.; Colla, G. An innovative vegetative propagation system for large-scale production of globe artichoke transplants. Part II. Propagation System validation. HortTechnology 2005, 15, 817-819. [CrossRef]

8. Riahi, J.; Nicoletto, C.; Bouzaein, G.; Sambo, P.; KoukiKhalfallah, K. Effect of vegetative propagation materials on globe artichoke production in semi-arid developing countries: agronomic, marketable and qualitative traits. Agronomy 2017, 7, 65. [CrossRef]

9. Harbaoui, Y. Multiplication "In Vitro" et Assainissement Viral de L'artichaut, Cynara scolymus L. Ph.D. Thesis, University De Gent, Gent, Belgium, 1982.

10. Ancora, G.; Saccardo, F. Carciofo: Nuove tecniche di propagazione. L'informatore Agrario 1987, 4, 53-55.

11. Rossi, V.; De Paoli, G. Micropropagation of artichoke (Cynara scolymus). In High-Tech and Micropropagation III; Bajaj, Y.P.S., Ed.; Springer: Berlin, Germany, 1992; pp. 118-134.

12. Morello, N.; Ierna, A.; Santoiemma, G.; Mauromicale, G. Improvement of "ovoli" production in globe artichoke by removal of the epigeal part of the plant. Acta Hort. 2005, 681, 251-255. [CrossRef]

13. Cline, M. Apical dominance. Bot. Rev. 1991, 57, 318-358. [CrossRef]

14. Wu, P.H.; Chang, D.C. Cytokinin treatment and flower quality in Phalaenopsis orchids: Comparing N-6-benzyladenine, kinetin and 2-isopentenyl adenine. Afr. J. Biotechnol. 2012, 11, 1592-1596.

15. Nambiar, N.; Siang, T.C.; Mahmood, M. Effect of 6- benzylaminopurine on flowering of a Dendrobium orchid. Aus. J. Crop Sci. 2012, 6, 225-231.

16. Haroun, S.A.; Shukry, W.M.; Abbas, M.A.; Mowafy, A.M. Growth and physiological responses of Solanum lycopersicum to atonik and benzyl adenine under vernalized conditions. J. Ecol. Nat. Environ. 2011, 3, 319.

17. Durrani, F.; Subhan, M.; Mehmood, S.; Abbas, S.; Chaudhary, F. Sarhad J. Enhancement of growth and yield components through foliar application of naphthalene acetic acid (NAA) and bezylaminopurine (BAP) in spinach. J. Agric. 2010, 26, 31.

18. Brutti, C.; Apostolo, N.M.; Ferrarotti, S.A.; Llorente, B.E.; Krymkiewicz, N. Micropropagation of Cynara scolymus L. employing cyclodextrins to promote rhizogenesis. Sci. Hort. 2000, 83, 1-10. [CrossRef]

19. Tavazza, R.; Papacchioli, V.; Ancora, G. An improved medium for in vitro propagation of globe artichoke (Cynara scolymus L.) cv. Acta Hortic. 2004, 660, 91-97. [CrossRef]

20. Apostolo, N.M.; Brutti, C.; Lorente, B. Leaf anatomy of Cynara scolymus L. In successive micropropagation stages. In Vitro Cell. Dev. Biol. Plant 2005, 41, 307-313. [CrossRef]

21. Schneider, F. Effect of Different Cultural Conditions on Micropropagation of Rose (Rosa sp. L.) and Globe Artichoke (Cynara scolymus L.). Ph.D. Thesis, Université Technique de Munich, München, Germany, 2005. 
22. Bekheet, S.A. In vitro Preservation of globe artichoke germplasm. Plant Tissue Cult. Biotech. 2007, 17, 1-9. [CrossRef]

23. Mauromicale, G.; Licandro, P.; Ierna, A.; Morello, N.; Santoiemma, G. Planning of globe artichoke plantlets production in nursery. Acta Hortic. 2004, 66, 279-284. [CrossRef]

24. El Boullani, R.; Elmoslih, A.; El Finti, A.; El Mousadik, A.; Serghini, M.A. Effect of decapitation and size of explants on In vitro multiplication rate of globe artichoke. Acta Hortic. 2013, 983, 325-329. [CrossRef]

25. Temperini, O.; Colla, G.; Saccardo, F. Artichoke: A new in vivo agamic propagation technique. Acta Hort. 2005, 681, 391-396. [CrossRef]

26. Campanelli, A.; Tagarelli, A.; De Mastro, G.; Morone-Fortunato, I.; Ruta, C. Innovative large-scale production of early artichoke transplants. Acta Hortic. 2013, 983, 331-335. [CrossRef]

27. He, H.; Qin, J.; Cheng, X.; Xu, K.; Teng, L.; Zhang, D. Effects of exogenous 6-BA and NAA on growth and contents of medicinal ingredient of Phellodendron chinense seedlings. Saudi J. Biol. Sci. 2018, 25, 1189-1195. [CrossRef]

28. De Lojo, J.; Di Benedetto, A. Biomass accumulation and leaf shape can be modulated by an exogenous spray of 6-benzylaminopurine in the ornamental foliage plant, Monstera deliciosa (Liebm.). J. Hortic. Sci. Biotechnol. 2014, 89, 136-140. [CrossRef]

29. Gao, Z.; Liang, X.G.; Zhang, L.; Lin, S.; Zhao, X.; Zhou, L.L.; Shen, S.; Zhou, S.L. Spraying exogenous 6-benzyladenine and brassinolide at tasseling increases maize yield by enhancing source and sink capacity. Field Crops Res. 2017, 211, 1-9. [CrossRef]

30. López-Bucio, J.; Cruz-Ramírez, A.; Herrera-Estrella, L. The role of nutrient availability in regulating root architecture. Curr. Opin. Plant Biol. 2003, 6, 280-287. [CrossRef]

31. Vreugdenhil, D.; Aarts, M.G.M.; Koornneef, M.; Nelissen, H.; Ernst, W.H.O. Natural variation and QTL analysis for cationic mineral content in seeds of Arabidopsis thaliana. Plant Cell Environ. 2004, 27, 828-839. [CrossRef]

32. Bondok, M.A.; Nadia, A.F.; Felaifel, M.S.E. The Effect of Some Triazole Compounds on the Productivity of Squash Plants; Mansoura University: Mansoura, Egypt, 1995; pp. 3677-3690.

33. Guo, C.; Oosterhuis, D.M.; Zhao, D. Ehancing Mineral Uptake of Cotton Plants with Plant Growth Regulators; Springer: Heidelberg, Germany, 1994; pp. 83-87.

34. Carey, D.; Buhler, W.; Whipker, B. Stimulating plant growth. Greenh. Prod. News 2009, 9, $20-24$.

35. Farris, M.E.; Keever, G.J.; Kessler, J.R.; Olive, J.W. Benzyladenine and cyclanilide promote shoot development and flowering of Coreopsis verticillatea 'Moonbean'. J. Environ. Hort. 2009, 27, 176-182.

36. Grossman, M.C. Use of Plant Growth Regulators to Improve Branching of Herbaceous Perennial Liners. Master's Thesis, Virginia Polytechnic Institute and State University, Blacksburg, VA, USA, 2012.

37. Bollmark, M.; Eliasson, L. Effects of exogenous cytokinins on root formation in pea cuttings. Physiol. Plant 1986, 68, 662-666. [CrossRef]

38. Laplaze, L.; Benkova, E.; Casimiro, I.; Maes, L.; Vanneste, S.; Swarup, R.; Weigers, D.; Calvo, V.; Parizot, B.; Herrera-Rodriguez, M.B.; et al. Cytokinins Act Directly on Lateral Root Founder Cells to Inhibit Root Initiation. Plant Cell 2017, 19, 3889-3900. [CrossRef]

39. Conversa, G.; La Rotonda, P.; Elia, A. Globe artichoke mother-plant management for the production of high quality offshoots. Acta Hortic. 2012, 942, 353-357. [CrossRef]

40. Shimizu-Sato, S.; Mori, H. Control of outgrowth and dormancy in axillary buds. Plant Physiol. 2001, 127, 1405-1413. [CrossRef]

41. Ha, S.; Vankova, R.; Yamaguchi-Shinozaki, K.; Shinozaki, K.; Tran, L.S.P. Cytokinins: metabolism and function in plant adaptation to environmental stresses. Trends Plant Sci. 2012, 17, 172-179. [CrossRef]

42. Werner, T.; Schmülling, T. Cytokinin action in plant development. Curr. Opin. Plant Biol. 2009, 12, 527-538. [CrossRef]

43. Ugur, A.; Eser, B. The effects of plant ages and cultivar on the offshoots yield and rooting of globe artichoke. Acta Hortic. 2013, 983, 387-392. [CrossRef]

44. Decourteix, M.; Alves, G.; Bonhomme, M.; Peuch, M.; Ben Baaziz, K.; Brunel, N. Sucrose (JrSUT1) and hexose (JrHT1 and JrHT2) transporters in walnut xylem parenchyma cells: their potential role in early events of growth resumption. Tree Physiol. 2008, 28, 215-224. [CrossRef]

45. Rameau, C.; Bertheloot, J.; Leduc, N.; Andrieu, B.; Foucher, F.; Sakr, S. Multiple pathways regulate shoot branching. Front. Plant Sci. 2015, 5, 1-15. [CrossRef] 
46. Chelle, M. Phylloclimate or the climate perceived by individual plant organs: What is it? How to model it? What for? New Phytol. 2005, 166, 781-790. [CrossRef]

47. Morris, S.E.; Cox, M.C.; Ross, J.J.; Krisantini, S.; Beveridge, C.A. Auxin dynamics after decapitation are not correlated with the initial growth of axillary buds. Plant Physiol. 2005, 138, 1665-1672. [CrossRef]

48. Bonhomme, M.; Peuch, M.; Ameglio, T.; Rageau, R.; Guilliot, A.; Decourteix, M.; Alves, G.; Sakr, S.; Lacointe, A. Carbohydrate uptake from xylem vessels and its distribution among stem tissues and buds in walnut (Juglans regia L.). Tree Physiol. 2010, 30, 89-102. [CrossRef]

49. Gupta, B.; Huang, B. Mechanism of Salinity Tolerance in Plants: Physiological, Biochemical, and Molecular Characterization. Inter. J. Geno. 2014, 1-18. [CrossRef]

50. Javid, M.G.; Sorooshzadeh, A.; Moradi, F.; Sanavy Seyed, A.M.M.; Allahdadi, I. The role of phytohormones in alleviating salt stress in crop plants. AJCS 2011, 5, 726-734.

51. Barciszewski, J.; Siboska, G.; Rattan, S.I.S.; Clark, B.F.C. Occurrence, biosynthesis and properties of kinetin (N6- furfuryladenine). Plant Growth Regul. 2000, 32, 257-265. [CrossRef]

52. Agarwal, P.; Dabi, M.; More, P.; Patel, K.; Jana, K.; Agarwal, P.K. Improved Shoot Regeneration, Salinity Tolerance and Reduced Fungal Susceptibility in Transgenic Tobacco Constitutively Expressing PR-10a Gene. Front. Plant Sci. 2016, 7, 217. [CrossRef]

53. Iqbal, M.; Ashraf, M.; Jamil, A. Seed enhancement with cytokinins: changes in growth and grain yield in salt stressed wheat plants. Plant Growth Regul. 2006, 50, 29-39. [CrossRef]

54. Wu, X.; Zhu, Z.; Li, X.; Zha, D. Effects of cytokinin on photosynthetic gas exchange, chlorophyll fluorescence parameters and antioxidative system in seedlings of eggplant (Solanum melongena L.) under salinity stress. Acta Physiol. Plant 2012, 34, 2105. [CrossRef]

55. Niazi, B.H.; Rozema, J.; Athar, M. Effect of pre-germination and post-germination treatment with growth hormones (kinetine and abscinic acid) on ion concentration and biochemical contents of fooderbeet and seabeet under saline conditions. Gen. Appl. Plant. Physiol. 2005, 31, 89-104.

56. Gent, M.P.N.; McAvoy, R.J. Plant Growth Retardants in Ornamental Horticulture. In Plant Growth Regulators in Agriculture and Horticulture: Their Role and Commercial Uses; Basra, A.S., Ed.; Food Products Press: New York, NY, USA, 2000; pp. 89-146.

57. Jackson, M.B.; Campbell, D.J. Effects of benzyladenine and gibberellic acid on the responses of tomato plants to anaerobic root environments and to ethylene. New Phytol. 1979, 82, 331. [CrossRef]

58. Kuiper, D.; Schuit, J.; Kuiper, P.J.C. Actual cytokinine concentrations in plant tissue as an indicator for saltresistance in cereals. Plant Soil 1990, 123, 243-250. [CrossRef]

59. Sakakibara, H. Cytokinin Biosynthesis and Metabolism. In Plant Hormones; Davies, P.J., Ed.; Springer: Dordrecht, The Netherlands, 2010.

60. Moffatt, B.; Pethe, C.; Laloue, M. Metabolism of benzyladenine is impaired in a mutant of Arabidopsis thaliana lacking adenine phosphoribosyltransferaseactivity. Plant Physiol. 1991, 95, 900-908. [CrossRef]

61. Thalooth, A.T.; Tawfik, M.M.; Mohamed, H.M. A comparative study on the effect of foliar application of zinc, potassium and magnesium on growth, yield and some chemical constituents of mungbean plants grown under water stress conditions. World J. Agric. Sci. 2006, 2, 37-46.

62. Cakmak, I. The role of potassium in alleviating detrimental effects of abiotic stresses in plants. J. Plant Nutr. Soil Sci. 2005, 168, 521-530. [CrossRef]

63. Vyas, S.P.; Garg, B.K.; Kathju, S.; Lahiri, A.N. Influence of potassium on water relations, photosynthesis, nitrogen metabolism and yield of clusterbean under soil moisture stress. Indian J. Plant Physiol. 2001, 6, 30-37.

64. Becker, D.; Hoth, S.; Ache, P.; Wenkel, S.; Roelfsema, M.R.G.; Meyerhoff, O.; Hedrich, R. Regulation of the ABA-sensitive Arabidopsis potassium channel gene GORK in response to water stress. FEBS Lett. 2003, 554, 119-126. [CrossRef]

65. Thalooth, A.T.; El-Zeiny, H.A.; Saad, A.O.M. Application of potassium fertilizer for increasing salt tolerance of broad bean (Vicia faba L.). Bull. Egypt Soc. Physiol. Sci. 1990, 10, 181-193.

(C) 2019 by the authors. Licensee MDPI, Basel, Switzerland. This article is an open access article distributed under the terms and conditions of the Creative Commons Attribution (CC BY) license (http:/ / creativecommons.org/licenses/by/4.0/). 